\title{
Studi tentang Faktor yang Mempengaruhi Niat untuk Mengundurkan Diri pada Operator Call Center
}

\author{
Aditya Wijoyo, Ari Yuda Laksmana, Banito Adiarto, Desy Arianty, Ng Pwee Hiong \\ School of Business and Economics Universitas Prasetiya Mulya \\ JL. RA. Kartini (TB Simatupang), Cilandak Barat Jakarta Selatan, Jakarta 12430 Indonesia \\ Corresponding Author: aditya.wijoyo@student.pmbs.ac.id
}

\begin{abstract}
Turn over intentions is related to many factors for call-center operators. Using the theoretical framework of the Job-Demands Resources model, this study exercises job demand, job resources (job autonomy and supervisor's support) and work engagement, to detect the influence of turnover intentions. The study involved 215 call-center operators in the Indonesian.

The resulting study suggests to improve job satisfaction thus it will lower the turnover intentions. Emotional dissonance exposes a negative correlation with job satisfaction and a positive correlation with turnover intentions. Job autonomy factor not related to job satisfaction and turnover while the supervisor's support not related directly to turnover intentions.
\end{abstract}

\begin{abstract}
Abstrak
Keinginan untuk keluar dari pekerjaan bagi operator call-center disebabkan banyak hal. Dengan menggunakan teori Job-Demands Resources model, penelitian ini menguji faktor tuntutan pekerjaan (disonansi emosi), sumber daya pekerjaan (kemandirian pekerjaan dan dukungan supervisor) serta keterlibatan pekerjaan untuk mencari besarnya pengaruh terhadap keinginan untuk keluar. Penelitian ini melibatkan 215 agen call-center di Indonesia.

Hasil penelitian menyarankan untuk memperbaiki kepuasan pekerjaan sehingga dapat menurunkan keinginan untuk keluar. Disonansi emosi memberikan hubungan negatif dengan kepuasan pekerjaan dan hubungan positif dengan keinginan untuk berhenti kerja. Kemandirian pekerjaan tidak berkorelasi dengan kepuasan pekerjaan dan keinginan berhenti kerja, juga dukungan atasan tidak berhubungan secara langsung dengan keinginan berhenti kerja.

\section{Kata Kunci}

Turnover Intention, Job Demand, Job Resources, Job Satisfaction, Work Engagement, Emotional Dissonance, Call Centre
\end{abstract}




\section{Pendahuluan}

Karyawan merupakan aset bagi perusahaan sehingga perusahaan akan melakukan pengelolaan sedemikian rupa agar tingkat keinginan untuk mengundurkan diri dapat diminimalisir, terutama bagi karyawan dengan kompetensi dan produktivitas yang tinggi, baik secara kuantitatif maupun kualitatif. Risiko terhadap pengunduran diri karyawan tersebut secara tidak langsung akan menyebabkan kerugian bagi perusahaan atas biaya yang telah dikeluarkan untuk merekrut, membina, memberikan pelatihan serta mempertahankan kompetensi dan integritas (Robinson 2006 dan Thite 2010) [16,20].

Perusahaan call-center adalah perusahaan jasa yang bertindak sebagai perwakilan suatu perusahaan untuk menjawab pelanggan dari perusahaan tersebut melalui telepon. Jasa yang disediakan meliputi penjualan, pemasaran, dukungan teknologi dan spesifik jasa lainnya (Abdullateef, Mokhtar, \& Yusoff, 2011) [1]. Oleh karena itu karyawan yang bekerja sebagai operator call-center menjadi bagian yang penting karena merepresentasikan kualitas perusahaan. Operator call-center bertanggungjawab untuk menyediakan layanan berkualitas tinggi kepada pelanggan (Ugwuowo,2010) [21], bahkan karena tuntutan persaingan penjualan maka kualitas dan kuantitas layanan menjadi hal yang vital bagi perusahaan (Labach, 2010) [12].

Untuk memastikan kualitas dan kuantitas layanan yang diberikan, telepon dari pelanggan dijawab dengan skrip dan manajer call-center melakukan monitor secara reguler (Kapoor \& Meachem, 2012) [14]. Selain skrip dan monitoring dari atasan, perusahaan menerapkan aturan agar operator kerap menampilkan respon emosi yang positif ketika menerima telepon dari pelanggan. Hal ini diberlakukan agar persepsi pelanggan terhadap jasa perusahaan yang direpresentasikan operator selalu positif. Namun demikian, kondisi emosi operator tidak selalu berada dalam kondisi positif. Operator harus selalu menampilkan emosi positif dalam kondisi apa pun termasuk saat dalam emosi tidak baik. Kondisi ini memungkinkan operator mengalami kondisi disonansi emosi yang menyebabkan ketidaknyamanan secara psikologis dan mengarah pada ketidakpuasan kerja dan berhenti kerja (Zito et.al. 2018) [23].

Ketika volume transaksi penjualan tinggi, perusahaan call-center akan menghadapi tuntuan yang tinggi dari pelanggan. Oleh karena itu, sistem renumerasi yang berdasarkan performansi serta sistem penghargaan lainnya perlu diberikan kepada operator call-center (Childs \& Donovan, 2012) [8]. Meskipun jika dibandingkan pekerjaan lain yang membutuhkan tingkat keahlian dan kompetensi yang lebih tinggi, gaji yang diterima operator call-center secara total masih dalam tingkat upah minimun bahkan kesempatan untuk berkarir 
pun tidak ada. Hal ini yang mensinyalir bahwa pekerjaan operator call-center hanya bersifat sementara (transitory), sehingga tingkat pengunduran diri menjadi tinggi.

Namun dalam sebuah penelitian di Italia, diketahui bahwa masa kerja seorang operator call-center ternyata dapat dibilang cukup lama, ada faktor lain yang mempengaruhi seperti kondisi ekonomi mengenai alternatif pasar tenaga kerja yang terbatas, tingginya tingkat pengangguran, dan tingkat keselamatan bekerja yang rendah (Zito et.al. 2008) [23].

Oleh karena itu, dengan mempertimbangkan kondisi tersebut diatas maka dilakukan riset di Indonesia untuk membuktikan teori hubungan Job Demand-Resources Model (Bakker \& Demerouti 2007 dan Bakker \& Demerouti 2014) [2,3]. Pentingnya peran tuntutan pekerjaan, model sumber daya berupa kemandirian kerja serta dukungan atasan, disonansi emosi dan keterlibatan kerja untuk menciptakan kepuasan bekerja dan keinganan untuk mengundurkan diri bagi para operator call-center pada perusahaan call-center di Indonesia.

\section{Tinjauan Pustaka \& Pengembangan Hipotesa}

\section{Job Demands-Resources Model - Model Tuntutan-Sumberdaya Pekerjaan}

Job Demands-Resources model (JD-R model) atau Model Tuntutan-Sumber daya Pekerjaan telah banyak didiskusikan dalam berbagai penelitian dan model ini secara fleksibel dapat digunakan dalam berbagai kondisi kerja dan pekerjaan yang berbeda (Zito et.al. 2018) [23]. JD-R model ini berasumsi bahwa kesehatan dan kesejahteraan karyawan dihasilkan dari keseimbangan karakteristik pekerjaan yang positif (sumber daya) dan negatif (tuntutan) (Schaufeli \& Taris 2014) [18]. Selanjutnya, Schaufeli \& Taris (2014) [18] menjelaskan bahwa di awal model JD-R ini didiskusikan mengusulkan dua proses pengembangan kondisi kelelahan, yaitu tuntutan pekerjaan yang berlebihan dalam jangka waktu yang panjang sehingga karyawan tidak mampu memulihkan dirinya, dapat mengarahkan pada aktivasi dan kelelahan berkelanjutan yang menghasilkan keletihan. Kedua adalah kurangnya sumber daya menghalangi pemenuhan tuntutan pekerjaan termasuk pencapaian tujuan yang mengarah pada perilaku menghindar. Dengan kata lain, tuntutan pekerjaan bertanggung jawab terhadap proses penurunan kesehatan, sedangkan sumber daya pekerjaan bertanggung jawab terhadap proses motivasi (Zito et.al 2018) [23].

Secara lebih spesifik, tuntutan pekerjaan didefinisikan sebagai aspek fisik, psikologi, sosial atau organisasional dari pekerjaan yang membutuhkan upaya atau kecakapan fisik dan/atau psikologi (kognisi dan emosi) yang berkelanjutan dan oleh karenanya berasosiasi dengan biaya psikologis (Zito et.al 2018) [23]. Sumber daya pekerjaan didefinisikan sebagai aspek fisik, psikologi, sosial, atau organisasional dari pekerjaan yang berfungsi dalam 
mencapai tujuan pekerjaan, mengurangi tuntutan pekerjaan dan diasosiasikan dengan biaya fisik dan psikologi; menstimulasi pertumbuhan pribadi, belajar dan pengembangan sebagaimana dikutip dari Zito et.al (2018) [23].

Peranan utama dari model ini dalam penelitian-penelitian yang dibahas untuk mencapai hasil yang positif, diperankan oleh keterlibatan kerja dan untuk hasil negatif adalah kelelahan. Namun demikian, Zito et.al (2018) [23] menjelaskan lebih lanjut dalam penelitiannya bahwa beberapa penelitian lainnya yang menggunakan model tersebut membahas juga mengenai kepuasan hidup dan kepuasan pekerjaan dalam konteks organisasi yang spesifik seperti call-center. Pada penelitian ini, peneliti mereplika penelitian yang dilakukan oleh Zito et.al. (2018) [23]

Pada berbagai penelitian, diskusi lebih banyak menekankan peran penting hubungan dengan atasan yang berkaitan dengan peranan coaching karyawan dalam bentuk kemitraan dalam bekerja, dengan atasan fokus pada kinerja, kebutuhan dan pengembangan karyawan. Dhanpat et.al (2018) [8] menjelaskan dalam penelitiannya bahwa menurut Dickel et.al (2006) [8] dukungan atasan merujuk pada perilaku atasan yang menjunjung tinggi keberlanjutan kinerja karyawan yang tinggi seperti imbalan, rekognisi dan umpan balik. Umpan balik yang sesuai dan berkala, penting untuk mempertahankan karyawan karena dukungan organisasi yang diterima akan meningkatkan komitmen afektif karyawan dalam jangka panjang. Selanjutnya dijelaskan menurut Van Dyk dan Coetzee (2012) dalam Dhanpat et.al (2018) [8] bahwa dukungan atasan dapat dilihat sebagai sumber kepercayaan dalam kemauan karyawan atau dorongan untuk menjadi yang terbaik dalam apapun yang mereka lakukan (Dhanpat et.al 2018) [8].

Sumber daya pekerjaan lainnya yang diteliti dalam penelitian ini adalah kemandirian bekerja yang merupakan derajat keleluasaan dalam pengelolaan pekerjaan. Kemandirian bekerja ini dianggap penting tidak hanya pada efek langsung terhadap indikator kesejahteraan di tempat kerja yang berbeda, tapi juga sebagai moderator dalam hubungan antara tuntutan pekerjaan dan hasil kesejahteraan. Lebih lanjut, Zito et.al (2018) [23] menjelaskan dalam call-center, kemungkinan untuk memiliki kemandirian kerja berhubungan dengan rendahnya stres, tingginya kepuasan kerja dan kinerja, serta berkonsekuensi pada rendahnya keinginan untuk berhenti bekerja. Oleh karena itu, peneliti memodifikasi hipotesa penelitian Zito et.al (2018) [23] menjadi 4 sub-hipotesa sebagai berikut:

Hipotesa 1a1: dukungan atasan mempunyai hubungan positif dengan kepuasan bekerja Hipotesa 1b1: dukungan atasan mempunyai hubungan negatif dengan keinginan berhenti kerja. 
Hipotesa 1a2: kemandirian bekerja mempunyai hubungan positif dengan kepuasan bekerja. Hipotesa 1b2: kemandirian bekerja mempunyai hubungan negatif dengan keinginan berhenti kerja.

\section{Disonansi Emosi}

Peters (2007) [14] dalam penelitiannya menjelaskan bahwa hubungan antara penyedia jasa dan nasabah dipersepsikan positif tergantung pada kemampuan penyedia jasa dalam menunjukkan emosi positif (contoh: simpati dan bersahabat) serta ketidakhadiran emosi negatif seperti takut, marah dan benci sebagaimana mengutip Grandey (2003) (Peters 2007) [14]. Lebih lanjut Ashfort dan Humphrey (1993) dalam Peters (2007) [14] menjelaskan, untuk memastikan kondisi tersebut tetap terjadi, organisasi menerapkan peraturan dalam menunjukkan emosi yang mana karyawan harus mematuhi aturan tersebut ketika berinteraksi dengan nasabah termasuk nasabah yang tidak bersahabat dan mereka menuntut karyawannya untuk meregulasi ekspresi emosi berdasarkan pada standar organisasi yang telah ditetapkan.

Dijelaskan pula dalam konteks jasa seperti call-center, pramugari atau pengasuh anak, aturan tersebut biasanya fokus pada penampilan emosi positif dan meredam emosi negatif. Ketika emosi positif yang ditampilkan tidak sesuai dengan emosi yang sebenarnya, menurut Middleton (1989) dan Morris \& Feldman (1969), kondisi tersebut disebut disonansi emosi (Middleton 1989; Morris \& Feldman 1996 dalam Peters 2007) [14].

Berdasarkan kerangka teori Grandey (2000) yang dipaparkan Peters (2007) [14] menjelaskan bahwa disonansi emosi dapat menghasilkan dua kelas konsekuensi yaitu berdampak pada individu terutama dalam hal kepuasan kerja, komitmen organisasi dan komponen tertentu dari kondisi kelelahan; di sisi lain merusak efek pada relevansi organisasi yang mengarah pada penurunan kinerja dan menginisiasi perilaku menghindar dari karyawan. Oleh karena itu dalam penelitiannya, Peters (2007) [14] menegaskan bahwa perubahan sikap individu terhadap kepuasan kerja dan hasil yang dapat diobservasi, dianggap tipe konsekuensi yang berbeda dalam disonansi emosi.

Sebagaimana dijelaskan lebih lanjut dalam penelitian Zito et.al (2018) [23] bahwa disonansi emosi ini selain mempengaruhi karyawan menilai kepuasan kerjanya, pengalaman emosi negatif yang dihasilkan dapat diasosiasikan kepada keinginan untuk berhenti kerja sebagai bentuk ketegangan emosi yang dialami karyawan untuk meninggalkan pekerjaan menyebabkan ketidaknyamanan psikologis dan berdampak pada kualitas kehidupan pekerjaan. Oleh karenanya, peneliti mereplika kembali hipotesis penelitian Zito et.al (2018) [23] sebagai berikut: 
Hipotesis 2a. Disonansi emosi memiliki hubungan negatif dengan kepuasan kerja

Hipotesis 2 b. Disonansi emosi memiliki hubungan positif dengan keinginan berhenti kerja

\section{Keterlibatan Kerja}

Sebagaimana dijelaskan sebelumnya bahwa salah satu peranan utama model JD-R ini diperankan oleh keterlibatan kerja. Shaufeli, Gonzalez dan Bakker (2002) dalam Peters (2007) [14] mendefinisikan keterlibatan kerja sebagai kondisi pikiran yang positif, memuaskan dan berkaitan dengan pekerjaan, dikarakteristikan oleh semangat, dedikasi dan penghayatan. Berdasarkan definisi ini, Peters (2007) [14] lebih lanjut menjelaskan bahwa keterlibatan kerja ini terdiri dari 3 aspek: (1) semangat mendeskripsikan kekuatan dan daya hidup yang membuat karyawan menggunakan usahanya dan bersikukuh dalam pencapaian meskipun menghadapi kendala, (2) dedikasi dijelaskan sebagai perasaan relevan terhadap tugas yang dikerjakan dan kemauan untuk berkontribusi dengan bangga, (3) penghayatan didefinisikan sebagai konsentrasi mendalam dan terlibat dengan dalam dan senang pada pekerjaan (Schaufeli et.al 2002 dalam Peters 2007) [14].

Lebih lanjut lagi, Schufeli dan Bakker (2004) dalam Peters (2007) [14] menunjukkan bahwa keterlibatan dan kinginan untuk berhenti kerja berasosiasi negatif. Sebagai konsekuensi dan menurut model Hom-Griffeth (1995) dalam Peters (2007) [14] mengenai pengunduran diri bahwa karyawan yang sangat terlibat yang kepuasan kerjanya tidak terganggu oleh kondisi yang penuh tekanan akan kurang rentan untuk secara sukarela keluar dari pekerjaan mereka. Oleh karena itu, mereplika hipotesis penelitian Peters (2007) [14], peneliti memformulasikan hipotesis sebagai berikut:

Hipotesis 3a: Keterlibatan kerja berhubungan positif dengan kepuasan kerja Hipotesis 3b: Keterlibatan kerja berhubungan negatif dengan keinginan untuk berhenti kerja

\section{Kepuasan Bekerja}

Penelitian ini meneliti peran dari tuntutan kerja spesifik dalan kaitannya dengan pekerjaan call center, disonansi emosi, keterlibatan kerja dan dua sumber daya pekerjaan yaitu kemandirian bekerja dan dukungan atasan dalam persepsi terhadap kepuasan kerja dan keinginan untuk berhenti kerja. Sheraz et.al (2014) [19] menjelaskan bahwa kepuasan kerja merupakan bagaimana seseorang berpikir dan merasakan tempat kerja mereka dan aspekaspek lain yang berbeda terkait hal tersebut. Lebih lanjut lagi dalam penelitiannya Sheraz et.al (2014) [19] mengutip Robbins (2003) bahwa kepuasan kerja merujuk pada keseluruhan sikap karyawan terhadadap pekerjaannya. Biasanya dipersepsikan berhubungan langsung dengan produktifitas dan juga kesejahteraan karyawan. Menurut Abraham (1999) dalam 
Sheraz et.al (2014) [19] menjelaskan ketika tingkat kepuasan kerja meningkat maka keinginan untuk berhenti kerja dianggap menurun.

Grandey (2000) dalam Peters (2007) [14] mengusulkan bahwa penurunan kepuasan kerja merupakan konsekuensi dari disonansi emosi. Locke \& Henne (1986) dalam Peters (2007) [14] mendefinisikan kepuasan kerja sebagai kondisi emosi yang menyenangkan dalam situasi kerja. Selain itu, kepuasan kerja dipengaruhi oleh faktor lain seperti gaji, lingkunan kerja, kemandirian, komunikasi dan komitmen organisasi (Rafael dan Enrique, 2009 dalam Ramamurthi et.al 2016) [15]. Kepuasan kerja sangat tinggi mempengaruhi resolusi karyawan apakah mereka akan pergi atau tetap bekerja di organisasi (Chen et.al 2011 dalam Imtiazossain et.al 2018) [9].

Penelitian ini mempertimbangkan kepuasan kerja sebagai mediator antara tuntutan dan sumberdaya dan hasil negatif seperti keinginan untuk berhenti kerja termasuk sebagai mediator antara keterlibatan kerja dan keinginan untuk berhenti kerja.

Hipotesis 4. Kepuasan kerja memiliki hubungan negatif dengan keinginan untuk berhenti kerja.

\section{Tingkat Pengunduran Diri (Turnover Intention)}

Akhirnya, penelitian ini juga mempertimbangkan keinginan untuk berhenti kerja, karena karyawan yang merasa tidak puas dalam pekerjaannya cenderung akan berhenti kerja dibandingkan mereka yang merasa puas, termasuk dalam konteks call-center. Pengunduran diri karyawan didefinisikan oleh Hom dan Griffeth (1995) dalam Peters (2007) [14] sebagai pemberhentian kerja secara sukarela yang dilakukan oleh anggota organisasi dan mereka mengidentifikasi keseluruhan ketidakpuasan pada pekerjaan adalah prakiraan terbaik untuk kecenderungan pengunduran diri (Peters 2007) [14].

Menurut penelitian Cote dan Morgan (2000) dalam Peters (2007) [14] menjelaskan bahwa kriteria model turnover dilihat dari sikap seseorang yang disebut sebagai keinginan mengundurkan diri atau berhenti kerja daripada tujuannya sebagai pengunduran diri aktual. Intensi ini diukur dengan cara menanyakan individu apakah mereka sedang berpikir tentang berhenti kerja. Lebih lanjut keinginan untuk berhenti didefinisikan sebagai rencana karyawan untuk meninggalkan atau berhenti dari pekerjaan atau perusahaan mereka saat itu dan melanjutinya dengan mencari penawaran kerja lain yang lebih baik (Purani dan Sahadev, 2008 dalam Ramamurthi 2016) [15].

Menurut Westlund (2007) dalam Nor et.al (2011) [13] menjelaskan bahwa keinginan untuk berhenti kerja diasosiasikan dengan rendahnya kepuasan kerja yang disebabkan oleh 
praktek supervisi manajer. Hal ini diperkuat oleh Smit, Stanz \& Bussin (2015) dalam Dhanpat (2018) [8] yang menyatakan bahwa keputusan untuk berhenti kerja diinisiasikan oleh ketidakpuasan yang disebabkan karena kondisi kerja seperti kurangnya keseimbangan kehidupan kerja, kurangnya uang, pekerjaan yang membosankan, supervisi yang jelek dan kurangnya peluang untuk berkembang dan pekerjaan call-center pada umumnya dikarakterisasi oleh kondisi kerja tersebut. Pengunduran diri karyawan ini berdampak negatif pada organisasi karena organisasi harus menanggung biaya pencarian, penerimaan dan pelatihan karyawan baru untuk mengganti karyawan yang berhenti kerja (Sheraz 2014) [19]. Oleh karenanya, organisasi memiliki minat dalam mencegah terjadinya turnover karyawan secara sukarela (Hom \& Griffeth, 1995 dalam Peters 2007) [14].

\section{Metodologi Penelitian}

Penelitian ini merupakan penelitian kuantitatif. Pengumpulan data dilakukan melalui penyebaran kuesioner yang terdiri dari 43 pertanyaan. Kuesioner dibagi menjadi 7 bagian. Bagian pertama berhubungan dengan profil demografi responden, bagian kedua berhubungan dengan pengukuran kepuasan bekerja, bagian ketiga berhubungan dengan dukungan atasan, bagian keempat berhubungan dengan disonansi emosi, bagian kelima berhubungan dengan kemandirian bekerja, bagian keenam berhubungan dengan turnover dan bagian ketujuh berhubungan dengan keterlibatan kerja.

Seluruh respon direkam dengan menggunakan google form dan dianalisa secara sistematis dengan menggunakan SPSS Version 25 untuk menggambarkan kesimpulan akhir.

Penelitian ini dilakukan di salah satu perusahaan call center di Indonesia dan melibatkan agen-agen call center sebagai responden. Pengisian kuesioner dilakukan melalui on-line dan nama responden dirahasiakan. Undangan dikirim ke 350 agen call center dan 215 agen yang mengisi kuesioner (61\% dari total responden).

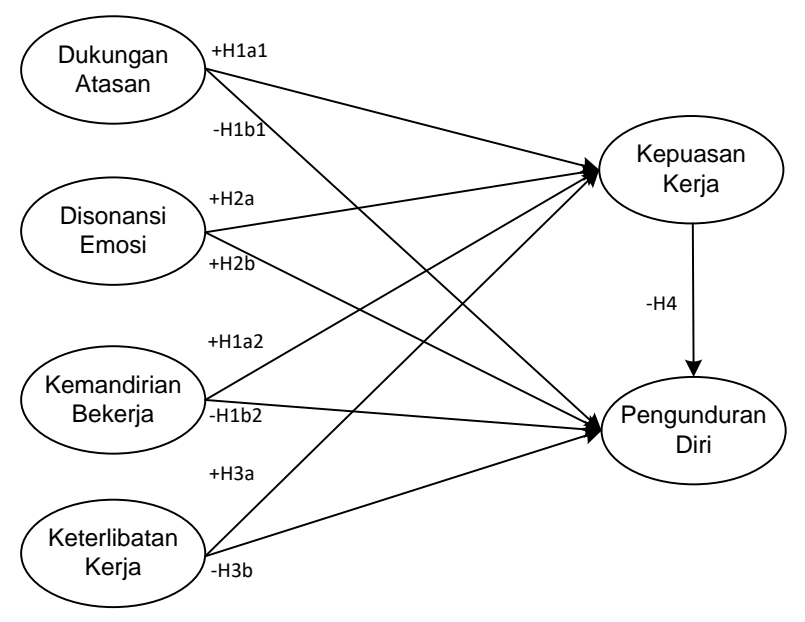


Gambar 1. Model penelitian

\section{Alat Ukur}

Jumlah total data responden 215 dengan 6 data responden tidak digunakan karena datanya tidak valid. Data demografi yang diambil dalam kuesioner meliputi jenis kelamin, umur, status perkawinan, kepemilikan anak, status pekerjaan, jadwal pekerjaan dan lama bekerja di perusahaan saat ini.

Berdasarkan model penelitian yang digunakan, riset ini memiliki 6 konstruk. Hasil analisa SPSS terhadap data responden yang ada, menghasilkan 7 konstruk. Hasil pengujian setiap konstruk menunjukkan konstruk keterlibatan kerja terpecah menjadi lebih dari 1 konstruk. Analisa penulis menemukan kuesioner no. 13.11, 13.13 dan 13.14 tidak mendukung konstruk keterlibatan kerja sehingga tidak digunakan untuk menilai. Hal ini menjadikan konstruk keterlibatan kerja dibentuk oleh 14 kuesioner.

\begin{tabular}{|l|r|r|r|} 
& \multicolumn{3}{c}{ Initial Eigenvalues } \\
\hline Component & \multicolumn{1}{c|}{ Total } & \% of Variance & Cumulative \% \\
\hline 1 & 12.472 & 37.794 & 37.794 \\
\hline 2 & 3.146 & 9.532 & 47.327 \\
\hline 3 & 2.158 & 6.539 & 53.866 \\
\hline 4 & 2.058 & 6.238 & 60.103 \\
\hline 5 & 1.550 & 4.697 & 64.801 \\
\hline 6 & 1.059 & 3.209 & 68.009 \\
\hline
\end{tabular}

Tabel 1. Eigenvalues untuk mengetahui jumlah konstruk.

Hasil pengujian 6 konstruk pada mode penelitian ini sebagai berikut :

1. Kepuasan Bekerja

Kepuasan bekerja diukur menggunakan 3 kuesioner yang digunakan oleh Copper et.al [7] dengan range skala Likert dari 1 (sangat tidak puas) sampai dengan 6 (sangat puas). Cronbach's alpha sebesar 0,901 dengan hasil pengukuran rata-rata kepuasan sebesar $4,30(\mathrm{SD}=0,93)$.

2. Dukungan Atasan

Dukungan atasan diukur menggunakan 4 kuesioner yang digunakan oleh Caplan et.al [5] dengan range skala Likert dari 1 (tidak ada) sampai dengan 6 (banyak). Cronbach's alpha sebesar 0,919 dengan hasil pengukuran rata-rata kepuasan sebesar 3,97 (SD = $1,12)$. 


\section{Disonansi Emosi}

Disonansi emosi diukur menggunakan 3 kuesioner yang digunakan oleh Zapf et.al [22] dengan range skala Likert dari 1 (tidak pernah) sampai dengan 6 (selalu). Cronbach's alpha sebesar 0,734 dengan hasil pengukuran rata-rata kepuasan sebesar 3,37 (SD = $1,04)$.

\section{Kemandirian Bekerja}

Kemandirian bekerja diukur menggunakan 6 kuesioner yang digunakan oleh Karasek dan Theorell [11] dengan range skala Likert dari 1 (tidak ada) sampai dengan 6 (banyak). Cronbach's alpha sebesar 0,804 dengan hasil pengukuran rata-rata kepuasan sebesar $4,23(\mathrm{SD}=0,82)$.

5. Pengunduran Diri (Turnover)

Tingkat pengunduran diri diukur menggunakan 3 kuesioner dari Michigan Organizational Assessment Questionnaire [4] dengan range skala Likert dari 1 (tidak setuju) sampai dengan 6 (setuju). Cronbach's alpha sebesar 0,758 dengan hasil pengukuran rata-rata kepuasan sebesar 3,47 $(\mathrm{SD}=1,15)$.

\section{Keterlibatan Kerja}

Keterlibatan dalam kerja diukur menggunakan 14 kuesioner Schaufeli dan Bakker [17] dengan range skala Likert dari 1 (tidak pernah) sampai dengan 6 (selalu). Cronbach's alpha sebesar 0,946 dengan hasil pengukuran rata-rata kepuasan sebesar 4,23 (SD = $0,88)$.

\section{Analisa Data}

Jumlah 209 koresponden yang digunakan untuk analisa memiliki nilai Kaiser-Meyer-Olkin (KMO) 0,915 (KMO > 0,5) dan nilai signifikan 0,000 $(<0,05)$, hal ini menunjukkan jumlah responden mencukupi untuk dianalisa. Lihat tabel 4. Keenam konstruk memiliki nilai Cronbach's alpha diatas 0,7 sehingga reliabilitas setiap konstruk tercapai. 
Vol. 4. No. 1, 2021

\section{Descriptive Statistics}

\begin{tabular}{l|r|r|r|r|r|r} 
& N & Minimum & Maximum & Mean & Std. Deviation & Variance \\
\hline Kepuasan_Bekerja & 209 & 1.67 & 6.00 & 4.2982 & .93132 & .867 \\
\hline Dukungan_Atasan & 209 & 1.00 & 6.00 & 3.9569 & 1.12283 & 1.261 \\
\hline Disonansi_Emosi & 209 & 1.00 & 6.00 & 3.3445 & 1.03897 & 1.079 \\
\hline Mandiri_Bekerja & 209 & 1.67 & 6.00 & 4.2225 & .82614 & .682 \\
\hline Pengunduran_Diri & 209 & 1.00 & 6.00 & 3.4561 & 1.15854 & 1.342 \\
\hline Keterlibatan_Kerja & 209 & 1.64 & 6.00 & 4.0198 & .88410 & .782 \\
\hline Valid N (listwise) & 209 & & & & & \\
\hline
\end{tabular}

Tabel 2. Statistik Deskriptif

\begin{tabular}{l|r|r}
\multicolumn{3}{c}{ KMO and Bartlett's Test } \\
\hline Kaiser-Meyer-Olkin Measure of Sampling Adequacy. & .915 \\
\hline \begin{tabular}{l|r} 
Bartlett's Test of \\
Sphericity
\end{tabular} & Approx. Chi-Square & 4850.258 \\
\cline { 2 - 3 } & df & 528 \\
\hline Sig. & .000 \\
\hline
\end{tabular}

Table 3. Pengujian KMO dan Bartlett

\section{Hasil}

Data demografi menunjukan bahwa dari 209 responden, 58,1\% adalah perempuan. Rentang umur responden dari 20 hingga 43 tahun dan rata-rata beumur 27 tahun. Status keluarga terdiri dari $65,1 \%$ belum menikah, $32,6 \%$ menikah, dan $76,3 \%$ belum mempunyai anak.

Pengalaman kerja mereka di perusahaan ini adalah 32,6\% responden masih di bawah 1 tahun, 35,3\% sudah bekerja selama 1 hingga 3 tahun, 13,5\% sudah bekerja selama $3-5$ tahun dan sisanya sudah bekerja lebih dari 5 tahun. Status pekerjaan mereka 99,5\% karyawan kontrak dan 91,6\% bekerja penuh waktu selama 40 jam seminggu. 
Hasil pengujian linearitas antar konstruk sesuai tabel di bawah ini.

\begin{tabular}{|c|c|c|c|c|c|c|}
\hline \multirow[b]{2}{*}{ Mode } & & \multicolumn{2}{|c|}{ Unstandardized Coefficients } & \multirow{2}{*}{$\begin{array}{c}\text { Standardized } \\
\text { Coefficients } \\
\text { Beta }\end{array}$} & \multirow[b]{2}{*}{$\mathrm{t}$} & \multirow[b]{2}{*}{ Sig. } \\
\hline & & $\mathrm{B}$ & Std. Error & & & \\
\hline \multirow[t]{5}{*}{1} & (Constant) & .868 & .253 & & 3.431 & .001 \\
\hline & Dukungan_Atasan & .135 & .043 & .163 & 3.118 & .002 \\
\hline & Disonansi_Emosi & -.081 & .039 & -.091 & -2.076 & .039 \\
\hline & Mandiri_Bekerja & .089 & .053 & .079 & 1.675 & .095 \\
\hline & Keterlibatan_Kerja & .695 & .056 & .659 & 12.331 & .000 \\
\hline
\end{tabular}

a. Dependent Variable: Kepuasan_Bekerja

Tabel 4. Regresi linear terhadap Kepuasan Bekerja

\begin{tabular}{|c|c|c|c|c|c|c|}
\hline \multirow[b]{2}{*}{ Mod } & & \multicolumn{2}{|c|}{ Unstandardized Coefficients } & \multirow{2}{*}{$\begin{array}{c}\text { Standardized } \\
\text { Coefficients } \\
\text { Beta }\end{array}$} & \multirow[b]{2}{*}{$t$} & \multirow[b]{2}{*}{ Sig. } \\
\hline & & B & Std. Error & & & \\
\hline \multirow[t]{6}{*}{1} & (Constant) & 4.361 & .480 & & 9.087 & .000 \\
\hline & Dukungan_Atasan & .077 & .082 & .075 & .949 & .344 \\
\hline & Disonansi_Emosi & .234 & .073 & .210 & 3.213 & .002 \\
\hline & Mandiri_Bekerja & .111 & .099 & .079 & 1.122 & .263 \\
\hline & Keterlibatan_Kerja & -.286 & .137 & -.219 & -2.087 & .038 \\
\hline & Kepuasan_Bekerja & -.305 & .129 & -.245 & -2.362 & .019 \\
\hline
\end{tabular}

a. Dependent Variable: Pengunduran_Diri

Tabel 6. Regresi linear terhadap Pengunduran Diri

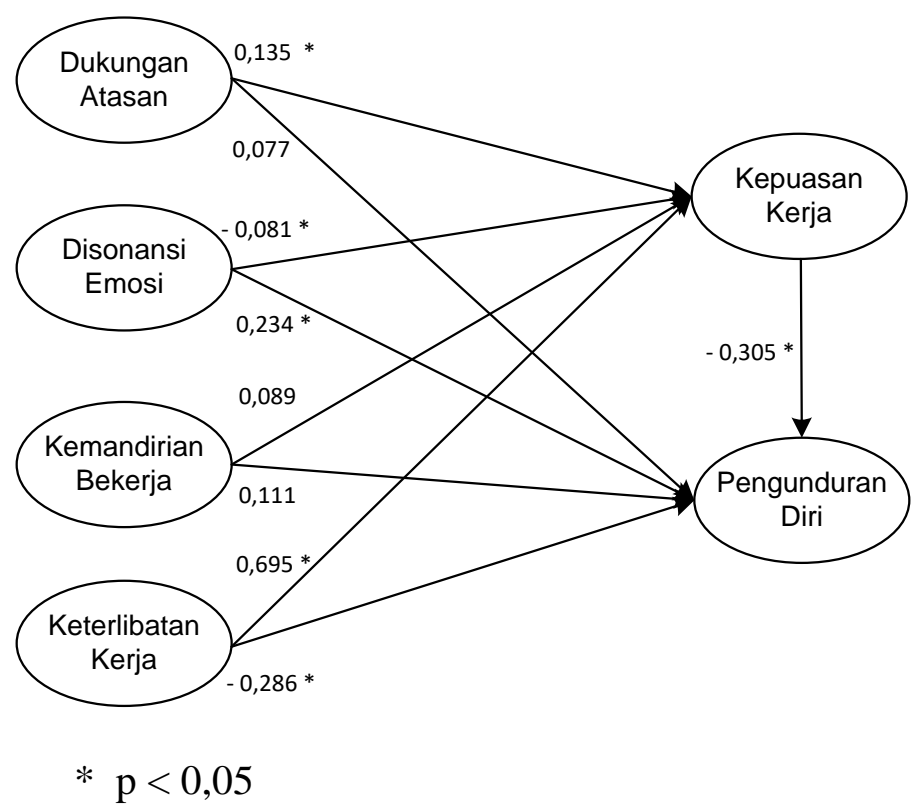

Gambar 2. Hasil model penelitian - unstandard paths.

Pada pengujian ini menunjukan bahwa konstruk Dukungan Atasan dan Keterlibatan Kerja memiliki hubungan positif dengan konstruk Kepuasan Bekerja sebesar 0,135 dan 
0,695, sedangkan konstruk Disonansi Emosi memiliki hubungan negatif terhadap Kepuasan Bekerja sebesar $-0,081$.

Keterhubungan Disonansi Emosi terhadap Pengundruan Diri bersifat positif sebesar 0,234 sedangkan hubungan Kepuasan Bekerja dan Keterlibatan Kerja terhadap Pengunduran Diri bersifat negatif masing-masing sebesar -0,305 dan -0,286.

\section{Diskusi}

Tujuan dari penelitian ini adalah untuk mendeteksi apakah faktor Job Resources (Sumber daya Pekerjaan), yang diwakili oleh dukungan atasan dan kemadirian bekerja, faktor disonansi emosi dan faktor keterlibatan bekerja berpengaruh terhadap keinginan untuk berhenti sebagai operator call-center. Penelitian terdahulu pada call center di Italia menguji faktor-faktor job demand dan job resources, mengacu kepada model JD-R, menunjukan bahwa ada faktor kepuasan bekerja yang dapat menyeimbangkan disonansi emosi (job demand) dan job resources disatu sisi dan turn over disisi lainnya. Pada penelitian ini, kami menambahkan faktor keterlibatan kerja untuk diuji juga pengaruhnya pada keinginan keluar.

Hipotesa 2a, adalah disonansi emosi akan berkorelasi negatif dengan kepuasan bekerja. Penelitian ini dapat mengkonfirmasi bahwa hipotesa ini benar dalam kasus ini. Hal ini menunjukan bahwa disonansi emosi, akan mengurangi kepuasan dalam bekerja. Sedangkan hipotesa $2 b$, juga dapat dikormasi oleh penelitian ini, bahwa disonansi emosi akan memberikan hubungan positif terhadap keinginan untuk keluar. Sejalan dengan hasil penelitian ini, beberapa studi sebelumnya (Neindemeyer, 2005 dan Bakker, 2003 dalam Zito et.al, 2018) [23] menunjukan bahwa disonansi emosi akan menurunkan semangat, keterlibatan, kemauan untuk melanjutkan pekerjaan.

Hipotesa 1a. Job resources (dukungan atasan dan kemandirian bekerja) mempunyai hubungan positif dengan kepuasan bekerja. Hipotesa 1b. Job resources (dukungan atasan dan Kemandirian bekerja) mempunyai hubungan negatif dengan keinginan berhenti kerja. Ketika kami uji hipotesa ini, kami menemukan bahwa faktor job resources tidak bisa dibuat dalam hipotesa yang sama karena ada hasil yang berlawanan. Untuk itu kami membuat sub-hipotesa lagi sehingga menjadi sebagai berikut:

a. Hipotesa 1a1: dukungan atasan mempunyai hubungan positif dengan kepuasan bekerja.

b. Hipotesa 1b1: dukungan atasan mempunyai hubungan negatif dengan keinginan berhenti kerja.

c. Hipotesa 1a2: kemandirian bekerja mempunyai hubungan positif dengan kepuasan bekerja. 
d. Hipotesa 1b2: kemandirian bekerja mempunyai hubungan negatif dengan keinginan berhenti kerja.

Hasil penelitian mengkonfirmasi hipotesa 1a1 bahwa dukungan atasan memberi nilai positif dalam kepuasan bekerja. Akan tetapi hipotesa 1a2 tidak dapat dikonfirmasi oleh penelitian ini karena hasilnya tidak signifikan sehingga dapat dibaikan hasilnya. Hal ini diluar ekspektasi, karena pada penelitian sebelumnya, oleh Zito et.al. (2018) [23], dapat mengkonfirmasi adanya hubungan negatif antara dukungan atasan dengan keinginan untuk berhenti kerja. Hasil temuan dari lapangan menunjukan adanya penggunaan naskah standar (skrip) yang harus digunakan dalam berkomunikasi dengan pelanggan, sehingga memang peran atasan kurang berpengaruh dalam pekerjaan ini.

Temuan yang berbeda dari penelitian sejenis sebelumnya adalah hipotesa 1a2 dan 1b2 keduanya tidak dapat dikonfirmasi oleh penelitian ini karena hasil pengolahan data menunjukan bahwa faktor kemandirian bekerja tidak cukup signifikan pengaruhnya dalam penelitian ini. Sama halnya dengan hipotesa H1b1, pada penelitian terdahulu oleh Zito et.al. (2018) [23], hipotesa ini dapat dikonfirmasi. Sama halnya dengan temuan diatas, penggunaan naskah standar (skrip) menghilangkan faktor kemandirian dalam bekerja. Staff call-center diwajibkan untuk menggunakan naskah untuk menjawab pertanyaan pelanggan untuk mengurangi kesalahan menjawab dan blunder, artinya mereka tidak diberikan keleluasaan dalam kemandirian melaksanakan tugas mereka. Temuan ini dapat menjawab mengapa faktor kemandirian kerja tidak relevan dalam penelitian ini.

Hipotesa H3a: keterlibatan kerja mempunyai hubungan positif dengan kepuasan bekerja.

Hipotesa H3b: keterlibatan kerja mempunyai hubungan negatif dengan keinginan berhenti kerja.

Hipotesa-hipotesa ini terkonfirmasi dalam penelitian ini. Ini menunjukan bahwa apabila karyawan merasa terlibat dalam pekerjaan, bangga dan bersemangat dalam melakukan perkerjaan, maka kepuasan bekerja akan meningkat dan menurunkan keinginan untuk keluar (Peters, 2007) [14].

Hipotesa 4, kepuasan bekerja mempunyai hubungan negatif dengan keinginan berhenti kerja. Hipotesa ini terkonfirmasi dengan baik dalam penelitian ini. Kepuasan bekerja dalam penelitian ini adalah gabungan dari disonansi emosi, dukungan atasan dan keterlibatan pekerjaaan. Semakin tinggi tingkat kepuasan pekerjaan maka keinginan untuk keluar akan berkurang. Artinya disini kepuasan bekerja merupakan faktor penting dalam mencegah pengunduran diri. 


\section{Kesimpulan}

Penelitian ini dibuat untuk menambah pengetahuan seberapa besar pengaruh job resources, dalam kerangka JD-R, terhadap keinginan untuk keluar. Selain itu penelitian ini juga menguji seberapa besar pengaruh keterlibatan kerja terhadap tingkat pengunduran diri, dan spesifik untuk bidang call-center, maka penelitian ini juga menguji seberapa besar disonansi emosi terhadap keinginan untuk keluar.

Penelitian ini menunjukan hasil yang berbeda dengan penelitian sejenis sebelumnya bahwa kemandirian dalam bekerja bukanlah faktor yang signifikan untuk menyebabkan tingginya tingkat pengunduran diri. Juga penelitian ini memberikan hasil bahwa dukungan dari atasan tidak memberi pengaruh langsung secara terhadap keinginan untuk berhenti kerja, walaupun masih memberi pengaruh negatif melalui kepuasan bekerja.

Disonansi emosi ini cukup unik dan sangat berpengaruh untuk perusahaan di sektor jasa pelayanan seperti call-center. Bukanlah hal yang mudah dan menyenangkan ketika karyawan selalu harus bersikap sopan dalam mengahadapi keluhan dan permintaan dari klien. Disonansi emosi ini mengakibatkan keinginan untuk keluar menjadi tinggi secara korelasi langsung atau tidak langsung sebagai bagian dari kepuasan bekerja. Penelitian ini juga memberikan hasil bahwa, keterlibatan kerja akan mengurangi keinginan untuk keluar dan keterlibatan kerja akan mempengaruhi secara positif terhadap kepuasan kerja.

Hasil penelitian di Indonesia agak berbeda dengan penelitian sebelumnya di Italia, Zito et.al (2018) [23]. Profil prekerja yang berbeda, usia, kebutuhan, dan lain-lain, membuat hasil penelitian ini menjadi berbeda. Temuan-temuan di lapangan seperti penggunaan naskah standar dalam menjawab pertanyaan pelanggan dapat menjelaskan mengapa faktor kemandirian kerja dan dukungan atasan tidak relevan dalam penelitian ini.

Secara managerial, langkah-langkah yang dapat diambil untuk menurunkan tingkat pengunduran diri diantaranya adalah sebagai berikut:

1. Meningkatkan dukungan atasan terhadap staff call-center sehingga nantinya dapat menurunkan secara langsung keinginan untuk keluar.

2. Meningkatkan keterlibatan karyawan dalam pelaksanaan tugas, dengan meningkatnya tanggung jawab pekerjaan, memberikan pelatihan, membuatkan jenjang karir, sehingga karyawan selalu bersemangat saat bekerja.

3. Untuk menekan disonansi emosi, perlu diadakan kegiatan-kegiatan yang dapat meningkatkan kemampuan regulasi emosi karyawan melalui sesi pelatihan, coaching, family gathering, rekognisi terhadap prestasi dan konsultasi psikologi. 
4. Kepuasan kerja adalah simpul utama pencegahan meningkatnya tingkat pengunduran diri, oleh karenanya program perbaikan dan pengembangan harus difokuskan kepada peningkatan kepuasan kerja. 


\section{Daftar Pustaka}

1. Abdullateef, A. O., Mokhtar, S. S. M., \& Yusoff, R. Z. (2011). The mediating effects of first call resolution on call centers' performance. Journal of Database Marketing \& Customer Strategy Management, 18, 16-30. doi:10.1057/dbm.2011.4

2. Bakker AB, Demerouti E. The job demands-resources model : state of the art. $J$ Manag Psycol.2007; 22(3);309-328. https://doi.org/10.1108/0268394071033115

3. Bakker AB, Demerouti E. Job demands-resources theory. In: Chen PY, Cooper CL, editors. Work and wellbeing. Wellbeing; a complete reference quide. Chichester, UK: Willey-Blackwell;2014, pp.37-64.

4. Cammann C, Fichman M, Jenkins GD, Klesh JR. Assessing the attitudes and perceptions of organizational members. In: Seashore SE, Lawler EE, Mirvis PH, Cammann C, editors. Assessing Organizational Change: A guide to methods, measures, and practices. New York: Wiley \& Sons, 1983. pp. 71-138.

5. Caplan RD, Cobb S, French JRP, Harrison RV, Pinneau SR. Job demands and worker health: Main effects and occupational differences. Washington: US Department of Health, Education, and Welfare; 1995.

6. Childs, K., \& Donovan, K. (2012). Managing and motivating today's contact-center workforce. Employment Relations Today (Wiley), 39(3), 29-35. doi:10.1002/ert.21374

7. Cooper CL, Sloan SJ, Williams S. OSI-Occupational Stress Indicator. Windsor: NFER Nelson; 1998.

8. Dhanpat, N. et.al. (2018), "Exploring employee retention and intention to leave within a call centre", dalam SA Journal of Human Resource Management, ISSN: (Online) 2071-078X, (Print) 1683-7584 (20 Maret 2018)

9. Imtiazossain, M. et.al (2018), "Factors Influencing Employee High Turnover Rate at Call Centres: A Case Study on AEON Credit Service Malaysia”, dalam IOSR Journal of Business and Management (IOSR-JBM), e-ISSN: 2278-487X, p-ISSN: 2319-7668. Volume 20, Issue 5. Ver. VIII. (May. 2018), PP 07-15, the IOS Website, www.iosrjournals.org

10. Kapoor, S., \& Meachem, A. (2012). Employee engagement- A bond between employee and organisation. Amity Global Business Review, 714-721. Retrieved from http://web.b.ebscohost.com/abstract?direct=true \&profile=ehost \&scope=site \&auth type $=$ crawler $\& j r n l=0975511 X \& A N=94327035 \& h=m C L T g D 6 z j b v 77 A S P J y 2 Z c 8$ 
KlBzD420YQNzJc9W52GTyBUNyL67sk\%2f5WwjSJKIlObd\%2fvXJOKvJ43md WRAT03cEQ\%3d\%

11. Karasek RA, Theorell T. Healthy Work: Stress, Productivity and the Reconstruction of Working Life. New York: Basic Books; 1990.

12. Labach, E. J. (2010). Improving customer retention through service quality at call centers. International Journal of Management and Information Systems, 14(3), 71-76. Retrieved from http://www.docsrush.net/2701058/international-journalofmanagement-information-systems.html

13. Nor, NNM. et.al. (2011), “Turnover Intention among Malaysian Operators in Electrical and Electronics Sub-Sector: Leadership Style Perspective”, dalam the Academia Website, https://www.academia.edu/9949384/TURNOVER_INTENTION_AMONG_MALAYSI AN_OPERATORS_IN_ELECTRICAL_AND_ELECTRONICS_SUBSECTOR_LEADERSHIP_STYLE_PERSPECTIVE.

14. Peters, C. (2007), “Longitudinal Relationships between Emotional Dissonance, Job Satisfaction, and Turnover - Moderated by Work Engagement and Lack of Reciprocity?", dalam Konstanzer Online-Publikations-System (KOPS), the Konztanz Website, http://kops.ub.uni-konstanz.de/volltexte/2009/8360/(September 2007)

15. Ramamurthi, K. et.al. (2016), "Impact of Job Stressors Factors on Employees' Intention to Leave Mediated by Job Engagement and Dispositional Factors”, dalam International Review of Management and Marketing, ISSN: 2146-4405 2016, 6(3), 528-531, the EconJournals Website, www.econjournals.com (2016)

16. Robinson G, Morley $C$, Call center management; responsibilities and performance. Int J Serv Ind Manag.2006; 1793):284-300. https://doi.org/10.1108/09564230610667122

17. Schaufeli, W. B., \& Bakker, A. B. (2003). Test manual for the Utrecht Work Engagement Scale. Unpublished manuscript, Utrecht University, the Netherlands. Retrieved from http://www.schaufeli.com.

18. Schaufeli, W.B. \& Taris, T.W. (2014), "A critical review of the Job DemandsResources Model: Implications for improving work and health", dalam G. Bauer \& O. Hämmig (Eds), Bridging occupational, organizational and public health(pp. 4368). Dordrecht: Springer.

19. Sheraz, A. et.al. (2014), “Antecedents of Job Stress and its impact on employee's Job Satisfaction and Turnover Intentions", dalam International Journal of Learning \& 
Development, ISSN 2164-4063 2014, Vol. 4, No. 2, the Macrothink Institute Website, www.macrothink.org/ijld (2014)

20. Thite $M$, Russell B. The next available agent; work organization in Indian call centres. New Tech Work Employ.2010; 25(1):2-18. https://doi.org/10.1111/j.1468005X.2009.00235.x

21. Ugwuowo, F. I. (2010). Time series modeling of daily abandoned calls in a call centre. Global Journal of Mathematical Sciences, 9, 57-65. doi:10.4314/gjmas.v9i1.62505

22. Zapf D, Vogt C, Seifert C, Mertini H, Isic A. Emotion work as a source of stress: The concept and the development of an instrument. Eur J Work Organ Psy. 1999; 8(3): 371-400. https://doi.org/10.1080/135943299398230

23. Zito, M. et.al. (2018), Turnover intentions in a call center: The role of emotional dissonance, job resources, and job satisfaction, dalam PLOS ONE, the Plos One Website, https://doi.org/10.1371/journal.pone.0192126 (February 5, 2018) 


\section{Lampiran}

Kuisoner Orisinal dan Terjemahan

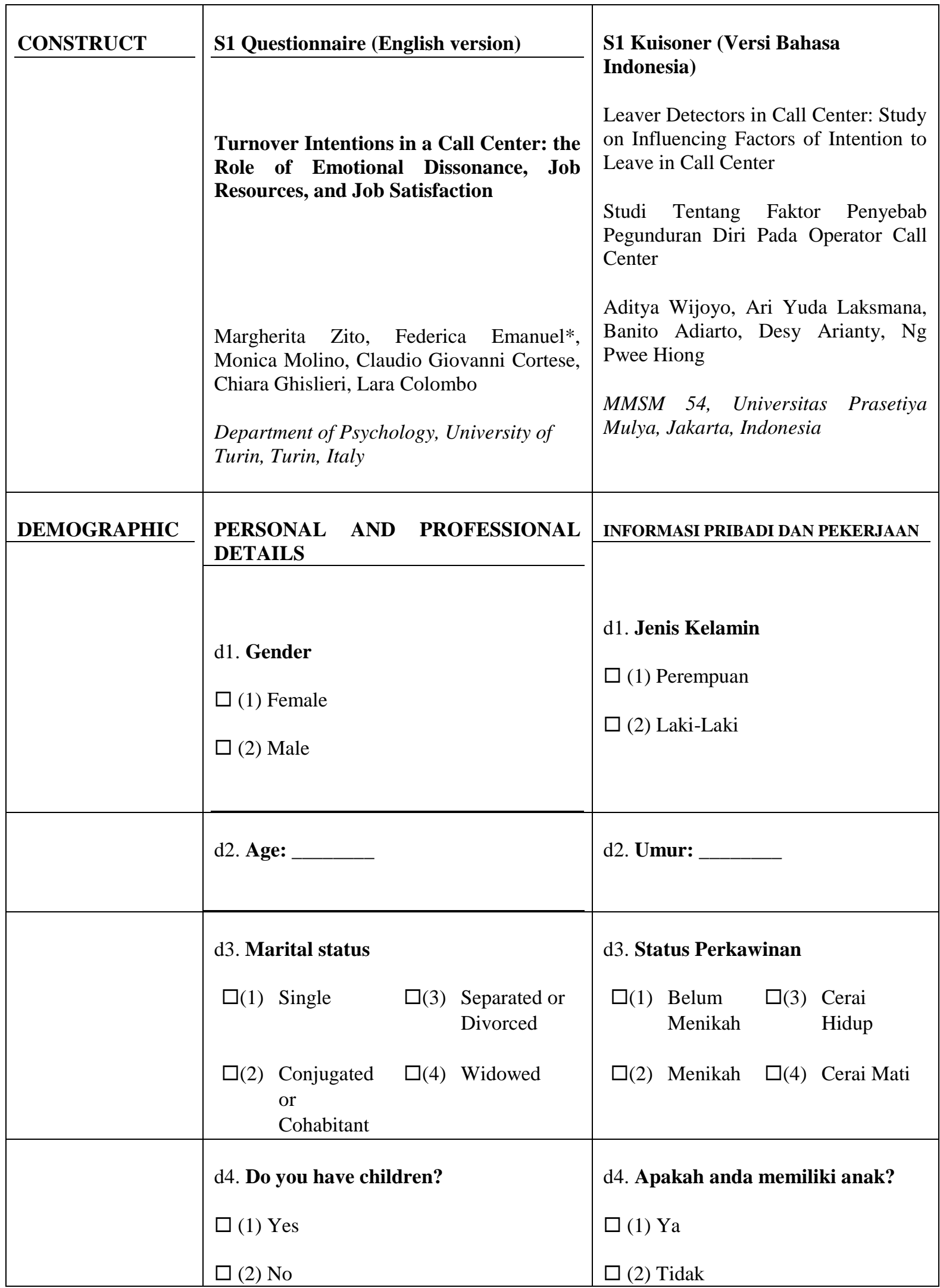




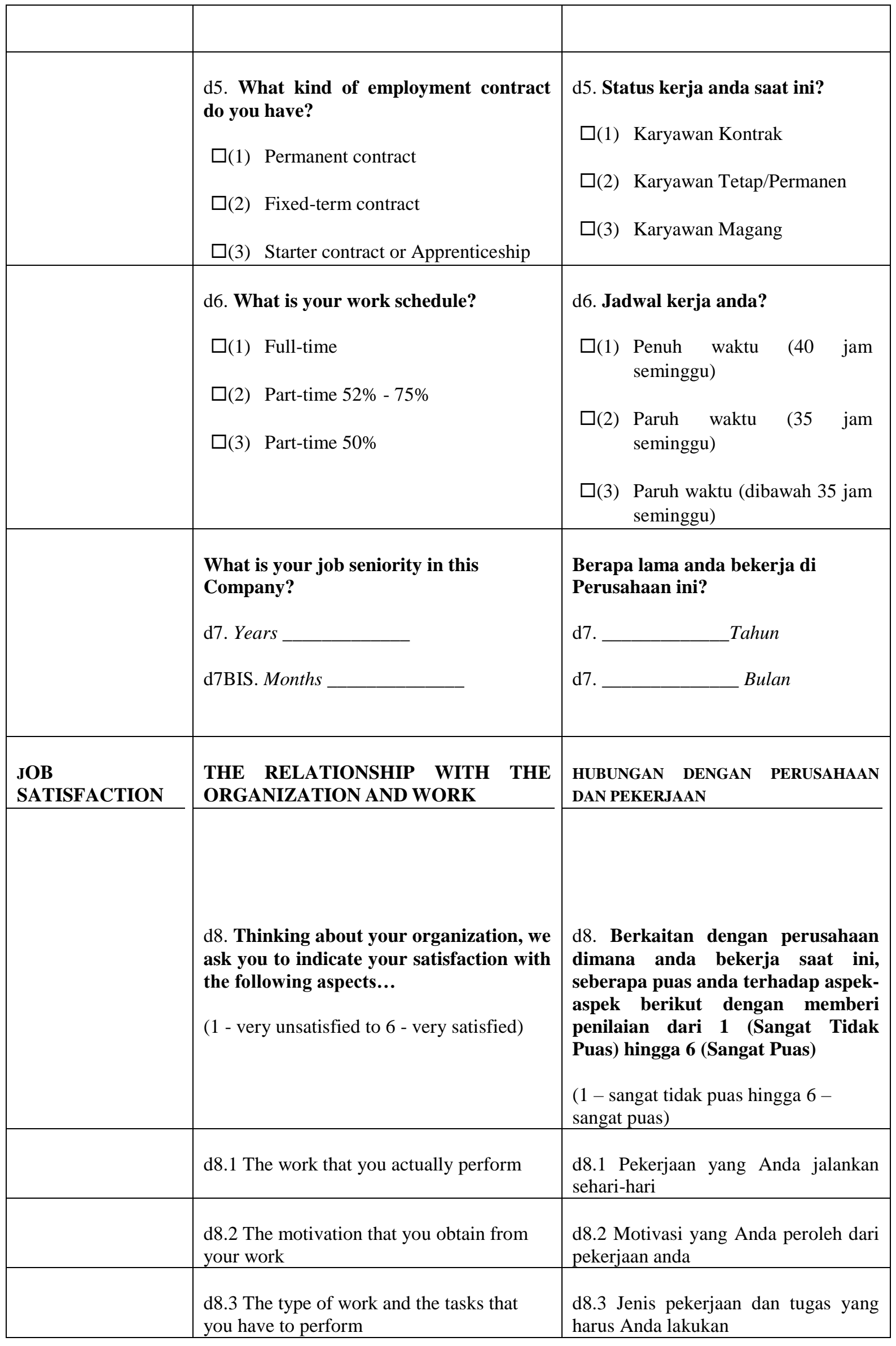




\begin{tabular}{|c|c|c|}
\hline \multirow[t]{5}{*}{$\begin{array}{l}\text { SUPERVISOR' } \\
\text { SUPPORT }\end{array}$} & $\begin{array}{l}\text { d9. Thinking about your supervisor, we } \\
\text { ask you to answer the following questions } \\
\text { (1-disagree to 6-agree) }\end{array}$ & $\begin{array}{l}\text { d9. Berkaitan dengan Atasan } \\
\text { langsung Anda, jawablah } \\
\text { pertanyaan-pertanyaan berikut }\end{array}$ \\
\hline & $\begin{array}{l}\text { d9.1 How much help does he/she offer to } \\
\text { face a serious labor problem? }\end{array}$ & $\begin{array}{l}\text { d9.1 Seberapa banyak bantuan yang } \\
\text { diberikan Atasan Anda untuk } \\
\text { mengatasi permasalahan pekerjaan } \\
\text { Anda? }\end{array}$ \\
\hline & $\begin{array}{l}\text { d } 9.2 \text { How much he/she is available to listen } \\
\text { to your professional problems? }\end{array}$ & $\begin{array}{l}\text { d9.2 Seberapa waktu yang diberikan } \\
\text { Atasan Anda untuk mendengarkan } \\
\text { permasalahan pekerjaan anda? }\end{array}$ \\
\hline & $\begin{array}{l}\text { d9.3 How much he/she helps you in } \\
\text { carrying out the daily work? }\end{array}$ & $\begin{array}{l}\text { d9.3 Seberapa banyak Atasan Anda } \\
\text { membantu dalam memecahkan } \\
\text { masalah pekerjaan harian Anda? }\end{array}$ \\
\hline & $\begin{array}{l}\text { d9.4 How much he/she is available to listen } \\
\text { to your personal problems? }\end{array}$ & $\begin{array}{l}\text { d9.4 Seberapa banyak waktu yang } \\
\text { disediakan Atasan Anda untuk } \\
\text { mendengarkan masalah pribadi Anda? }\end{array}$ \\
\hline \multirow[t]{4}{*}{$\begin{array}{l}\text { EMOTIONAL } \\
\text { DISSONANCE }\end{array}$} & $\begin{array}{l}\text { d10. In your work day, how often to... } \\
(1-\text { never to } 6 \text { - always })\end{array}$ & $\begin{array}{l}\text { d10. Di hari kerja Anda, seberapa } \\
\text { sering Anda... } \\
(1-\text { tidak pernah, hingga } 6 \text { - selalu })\end{array}$ \\
\hline & $\begin{array}{l}\text { d10.1 Display emotions which do not } \\
\text { correspond to inner feelings }\end{array}$ & $\begin{array}{l}\text { d10.1 Menunjukkan emosi yang tidak } \\
\text { berhubungan dengan perasaan dalam } \\
\text { diri Anda yang sebenarnya }\end{array}$ \\
\hline & $\begin{array}{l}\text { d10.2 Display positive emotions while } \\
\text { feeling indifferent }\end{array}$ & $\begin{array}{l}\text { d10.2 Menunjukkan emosi positif } \\
\text { walaupun sebenarnya merasa biasa } \\
\text { saja }\end{array}$ \\
\hline & $\begin{array}{l}\text { d10.3 Force yourself to show certain } \\
\text { feelings }\end{array}$ & $\begin{array}{l}\text { d10.3 Memaksakan diri Anda sendiri } \\
\text { untuk menunjukkan perasaan-perasaan } \\
\text { tertentu }\end{array}$ \\
\hline \multirow[t]{2}{*}{ JOB AUTONOMY } & $\begin{array}{l}\mathrm{d} 11 \text {. Indicate your degree of autonomy in } \\
\text { relation to the following situations } \\
(1-\text { none to } 4-\mathrm{a} \text { lot })\end{array}$ & $\begin{array}{l}\text { d11. Seberapa besar tingkat } \\
\text { kemandirian Anda dalam ... } \\
(1-\text { tidak ada, hingga } 6 \text { - banyak })\end{array}$ \\
\hline & d11.1 $\ldots$ to determine the method of & d11.1 ... menentukan sendiri metoda \\
\hline
\end{tabular}


Vol. 4. No. 1, 2021

\begin{tabular}{|c|c|c|}
\hline & working yourself & bekerja anda \\
\hline & $\begin{array}{l}\mathrm{d} 11.2 \ldots \text { to choose tasks and activities to be } \\
\text { performed }\end{array}$ & $\begin{array}{l}\text { d11.2 ... memilih tugas-tugas dan } \\
\text { aktifitas yang harus dilakukan }\end{array}$ \\
\hline & $\begin{array}{l}\mathrm{d} 11.3 \ldots \text { to decide on the quality of your } \\
\text { work }\end{array}$ & $\begin{array}{l}\text { d11.3 ... memutuskan kualitas kerja } \\
\text { anda }\end{array}$ \\
\hline & $\begin{array}{l}\mathrm{d} 11.4 \ldots \text { to determine the amount of work to } \\
\text { be done during a certain period yourself }\end{array}$ & $\begin{array}{l}\text { d11.4 ... menentukan sendiri jumlah } \\
\text { pekerjaan yang harus Anda kerjakan } \\
\text { dalam kurun waktu tertentu }\end{array}$ \\
\hline & $\begin{array}{l}\mathrm{d} 11.5 \ldots \text { to raise or lower the pace of work } \\
\text { yourself }\end{array}$ & $\begin{array}{l}\text { d11.5 } \quad \ldots \quad \text { meningkatkan } r \\
\text { menurunkan } \\
\text { dalam bendiri kecepatan } \\
\text { Anda }\end{array}$ \\
\hline & $\begin{array}{l}\mathrm{d} 11.6 \text {... to pause in your work whenever } \\
\text { you want }\end{array}$ & $\begin{array}{l}\text { d11.6 ... berhenti sebentar saat bekerja } \\
\text { kapanpun Anda mau }\end{array}$ \\
\hline $\begin{array}{l}\text { TURNOVER } \\
\text { INTENTION }\end{array}$ & $\begin{array}{l}\text { d12. Thinking to your work, indicate } \\
\text { your agree with the following statements } \\
(1-\text { disagree to } 4 \text { - agree })\end{array}$ & $\begin{array}{l}\text { d12. Berkaitan dengan pekerjaan } \\
\text { anda, tentukan persetujuan anda } \\
\text { terhadap pernyataan-pernyataan } \\
\text { berikut } \\
(1 \text { - tidak setuju, hingga } 6 \text { - setuju })\end{array}$ \\
\hline & d12.1 I often think about quitting my job & $\begin{array}{l}\text { d12.1 Saya sering berpikir untuk } \\
\text { berhenti dari tempat bekerja sekarang }\end{array}$ \\
\hline & d12.2 I often read job offers & $\begin{array}{l}\text { d12.2 Saya sering membaca lowongan } \\
\text { pekerjaan }\end{array}$ \\
\hline & $\begin{array}{l}\mathrm{d} 12.3 \text { A job with a similar salary in another } \\
\text { organization would be an interesting } \\
\text { alternative to my current job }\end{array}$ & $\begin{array}{l}\text { d12.3 Pekerjaan dengan gaji yang } \\
\text { sama di perusahaan lain akan menjadi } \\
\text { alternatif yang menarik bagi saya }\end{array}$ \\
\hline $\begin{array}{l}\text { WORK } \\
\text { ENGAGEMENT }\end{array}$ & $\begin{array}{l}\text { The following } 17 \text { statements are about how } \\
\text { you feel at work. Please read each statement } \\
\text { carefully and decide if you ever feel this } \\
\text { way about your job. If you have never had } \\
\text { this feeling, cross the "0" (zero) in the } \\
\text { space after the statement. If you have had } \\
\text { this feeling, indicate how often you feel it } \\
\text { by crossing the number (from } 1 \text { to } 6 \text { ) that } \\
\text { best describes how frequently you feel that } \\
\text { way }\end{array}$ & $\begin{array}{l}17 \text { pernyataan berikut menunjukkan } \\
\text { bagaimana perasaan Anda di tempat } \\
\text { kerja. Silahkan baca baik-baik } \\
\text { pernyataan berikut dan tentukan jika } \\
\text { Anda pernah memiliki perasaan } \\
\text { tersebut tentang pekerjaan Anda. Jika } \\
\text { tidak pernah merasakannya, pilih } \\
\text { angka "1" (satu) setelah pernyataan } \\
\text { yang dimaksud. Jika Anda pernah } \\
\text { merasakannya, tentukan seberapa } \\
\text { sering Anda merasakannya dengan } \\
\text { memilih angka (dari } 2 \text { ke } 6 \text { ) yang } \\
\text { paling menggambarkan seberapa } \\
\text { sering Anda merasakan hal tersebut. }\end{array}$ \\
\hline $\begin{array}{l}\text { Vigor } \\
\text { (Bersemangat) }\end{array}$ & $\begin{array}{l}\text { 1. At my work, I feel bursting with energy. } \\
\text { (vigor) }\end{array}$ & $\begin{array}{l}\text { 1. Di tempat kerja, saya merasa sangat } \\
\text { bersemangat }\end{array}$ \\
\hline $\begin{array}{l}\text { Dedication } \\
\text { (Berdedikasi) }\end{array}$ & $\begin{array}{l}\text { 2. I find the work that I do full of meaning } \\
\text { and purpose. (dedication) }\end{array}$ & $\begin{array}{l}\text { 2. Saya berpendapat bahwa pekerjaan } \\
\text { yang saya lakukan penuh dengan }\end{array}$ \\
\hline
\end{tabular}


Vol. 4. No. 1, 2021

\begin{tabular}{|c|c|c|}
\hline & & makna dan tujuan \\
\hline $\begin{array}{l}\text { Absorption } \\
\text { (Berkonsentrasi } \\
\text { penuh) }\end{array}$ & $\begin{array}{l}\begin{array}{l}\text { 3. Time flies when I'm working. } \\
\text { (absorption) }\end{array} \\
\end{array}$ & $\begin{array}{l}\text { 3. Waktu berlalu dengan cepat ketika } \\
\text { saya bekerja }\end{array}$ \\
\hline $\begin{array}{l}\text { Vigor } \\
\text { (Bersemangat) }\end{array}$ & $\begin{array}{l}\text { 4. At my job, I feel strong and vigorous. } \\
\text { (vigor) }\end{array}$ & $\begin{array}{l}\text { 4. Di pekerjaan saya, saya merasa kuat } \\
\text { dan bersemangat }\end{array}$ \\
\hline $\begin{array}{l}\text { Dedication } \\
\text { (Berdedikasi) }\end{array}$ & $\begin{array}{l}\text { 5. I am enthusiastic about my job. } \\
\text { (dedication) }\end{array}$ & $\begin{array}{l}\text { 5. Saya antusias dengan pekerjaan } \\
\text { saya }\end{array}$ \\
\hline $\begin{array}{l}\text { Absorption } \\
\text { (Berkonsentrasi } \\
\text { penuh) }\end{array}$ & $\begin{array}{l}\text { 6. When I am working, I forget everything } \\
\text { else around me. (absorption) }\end{array}$ & $\begin{array}{l}\text { 6. Ketika saya bekerja, saya lupa } \\
\text { segala sesuatu yang ada di sekitar saya }\end{array}$ \\
\hline $\begin{array}{l}\text { Dedication } \\
\text { (Berdedikasi) }\end{array}$ & 7. My job inspires me. (dedication) & 7. Pekerjaan saya menginspirasi saya \\
\hline $\begin{array}{l}\text { Vigor } \\
\text { (Bersemangat) }\end{array}$ & $\begin{array}{l}\text { 8. When I get up in the morning, I feel like } \\
\text { going to work. (vigor) }\end{array}$ & $\begin{array}{l}\text { 8. Ketika saya bangun di pagi hari, } \\
\text { saya merasa ingin bekerja }\end{array}$ \\
\hline $\begin{array}{l}\text { Absorption } \\
\text { (Berkonsentrasi } \\
\text { penuh) }\end{array}$ & $\begin{array}{l}\text { 9. I feel happy when I am working } \\
\text { intensely. (absorption) }\end{array}$ & $\begin{array}{l}\text { 9. Saya merasa senang ketika saya } \\
\text { bekerja secara intens }\end{array}$ \\
\hline $\begin{array}{l}\text { Dedication } \\
\text { (Berdedikasi) }\end{array}$ & $\begin{array}{l}\text { 10. I am proud of the work that I do. } \\
\text { (dedication) }\end{array}$ & $\begin{array}{l}\text { 10. Saya bangga dengan pekerjaan } \\
\text { yang saya lakukan }\end{array}$ \\
\hline $\begin{array}{l}\text { Absorption } \\
\text { (Berkonsentrasi } \\
\text { penuh) }\end{array}$ & $\begin{array}{l}\text { 11. I am immersed in my work. } \\
\text { (absorption) }\end{array}$ & $\begin{array}{l}\text { 11. Saya tenggelam dalam pekerjaan } \\
\text { saya }\end{array}$ \\
\hline $\begin{array}{l}\text { Vigor } \\
\text { (Bersemangat) }\end{array}$ & $\begin{array}{l}\text { 12. I can continue working for very long } \\
\text { periods at a time. (vigor) }\end{array}$ & $\begin{array}{l}\text { 12. Saya dapat terus bekerja untuk } \\
\text { waktu yang sangat lama }\end{array}$ \\
\hline $\begin{array}{l}\text { Dedication } \\
\text { (Berdedikasi) }\end{array}$ & $\begin{array}{l}\text { 13. To me, my job is challenging. } \\
\text { (dedication) }\end{array}$ & $\begin{array}{l}\text { 13. Bagi saya, pekerjaan saya } \\
\text { menantang }\end{array}$ \\
\hline $\begin{array}{l}\text { Absorption } \\
\text { (Berkonsentrasi } \\
\text { penuh) }\end{array}$ & $\begin{array}{l}\text { 14. I get carried away when I'm working. } \\
\text { (absorption) }\end{array}$ & 14. Saya terbawa suasana saat bekerja \\
\hline $\begin{array}{l}\text { Vigor } \\
\text { (Bersemangat) }\end{array}$ & $\begin{array}{l}\text { 15. At my job, I am very resilient, mentally. } \\
\text { (vigor) }\end{array}$ & $\begin{array}{l}\text { 15. Di pekerjaan saya, saya secara } \\
\text { mental sangat ulet }\end{array}$ \\
\hline $\begin{array}{l}\text { Absorption } \\
\text { (Berkonsentrasi } \\
\text { penuh) }\end{array}$ & $\begin{array}{l}\text { 16. It is difficult to detach myself from my } \\
\text { job. (absorption) }\end{array}$ & $\begin{array}{l}\text { 16. Sulit untuk melepaskan diri dari } \\
\text { pekerjaan saya }\end{array}$ \\
\hline $\begin{array}{l}\text { Vigor } \\
\text { (Bersemangat) }\end{array}$ & $\begin{array}{l}\text { 17. At my work I always persevere, even } \\
\text { when things do not go well. (vigor) }\end{array}$ & $\begin{array}{l}\text { 17. Di pekerjaan saya, saya selalu } \\
\text { bertahan, bahkan ketika segala } \\
\text { sesuatunya tidak berjalan dengan baik }\end{array}$ \\
\hline
\end{tabular}

